\title{
Changes in the Function of Allotment Gardens in an Attractive Location Based on the Example of Tri-City in Poland
}

\author{
Żaneta Moskalonek, Marcin Połom * ${ }^{\mathbb{C}}$ and Krystian Puzdrakiewicz \\ Division of Regional Development, Faculty of Oceanography and Geography, University of Gdańsk, \\ Bażyńskiego 4, 80-309 Gdańsk, Poland; z.moskalonek.377@studms.ug.edu.pl (Ż.M.); \\ krystian.puzdrakiewicz@ug.edu.pl (K.P.) \\ * Correspondence: marcin.polom@ug.edu.pl
}

Received: 28 October 2020; Accepted: 18 November 2020; Published: 19 November 2020

check for updates

\begin{abstract}
Allotment gardens are quite common in many European countries. In particular, they are an important part of the urban space in Central and Eastern Europe. They served to improve the inhabitants' physical and mental well-being during the communist period and relieved the family budget thanks to their own crops. The article analyzes the functioning of allotment gardens in Poland based on the example of the Tri-City, with particular emphasis on allotment gardens in a prestigious, attractive location. Several research questions were asked regarding the change of the traditional function related to growing fruit and vegetables towards the modern function related to recreation and relaxation. A thesis was put forward that the attractive, seaside location of one of the allotment gardens on the border of Gdańsk and Sopot favors the dynamics of the changes in the function. New garden houses often resemble residential apartments in terms of comfort and function and are used for commercial rent during the summer, even though this is prohibited. In the study, the methods of a field query as well as a questionnaire survey and an in-depth interview were applied to check the state of the allotment holders' knowledge on the applicable regulations regarding the functions of allotment gardens and their development, the size of garden houses and the rules of staying in the gardens, in particular living there. The questionnaire research and in-depth interviews were conducted at the beginning of 2020. The questionnaire research was conducted in February and March, and the in-depth interviews in May. The most pressing issues concerned the changing functions of allotment gardens and the perception of these changes by allotment owners who have gardens in a traditional form of cultivation. This study also allowed looking at possible neighborhood conflicts that may arise from a change in the function, in particular from the construction of houses with residential facilities, which encourages permanent residence in them, and sometimes subletting to tourists due to their attractive coastal location. The study helped to deepen the knowledge on the functioning of allotment gardens and transforming their functions into residential ones during the summer season. The obtained results show that nearly $60 \%$ of the surveyed respondents believe that seasonal occupation of allotment gardens should be allowed if their owners wish to do so. Most of the respondents encountered the problem of abnormal buildings and believe that the regulations in this respect should be followed. At the same time, they do not think that it is causing any problems for them. Conducting in-depth interviews, the information was obtained that the change of functions does not affect the existing, traditional users, and they mostly accept the changes taking place.
\end{abstract}

Keywords: allotment gardens; seaside; gardening; recreational; prestigious location; holiday home 


\section{Introduction}

Since the earliest times, houses in cities had gardens where people grew food and sometimes raised animals. Therefore, it was a specific process of locating rural functions in the city. Gardens accessible to various social groups on the city's outskirts date back to at least 4000 years ago in Persia. Yet the plots as we know them today have their origins at the end of the 19th century [1].

One of the ways of solving the problems related to the dynamic growth of the urban population and industrialization in Western Europe in the 19th century was to create collective allotment gardens to grow fruit and vegetables. The peak of popularity of this phenomenon took place during World War I and II [2]. The popularity of allotment gardens decreased in the second half of the 20th century, along with smaller food shortages. Another turn towards such spaces took place with an increase in ecological awareness, care for the climate and nature. Due to the worse economic situation after World War II, allotment gardens were particularly popular in Eastern Europe. They allowed avoiding poverty through the availability of basic produce. It was very common that owners of allotment gardens raised slaughter animals (pigs) as well as poultry (chickens, ducks, geese) and rabbits. The functioning of allotment gardens in Eastern Europe was part of the planned economy.

After World War II, Western Europe underwent impressive urban renewals, yet not including allotment gardens as a proper measure to guarantee a better quality of life [3]. By contrast, in Eastern Europe this features allowed avoiding poverty through the availability of basic products. This trend is even maintained with the urban regeneration of Western countries in the logic of capital [4] that provided other types of green spaces along with the new icons of capitalism [5] that contribute to gentrification [6] and not guarantee the right to the city [7,8]. Allotment gardens in Poland are particularly interesting because their users constitute the largest percentage of people cultivating the land. In 1997, garden users celebrated 100 years of formal operation. The allotment movement in Poland is rooted in the country's agricultural past and is associated with the transfer of labor from rural areas to cities without infrastructure to meet their basic needs [9]. The organization of allotment gardens in Poland during the communist period was associated with food security, and nowadays more and more often it is related to a desire to have a "second home" for recreational purposes.

The article attempts to analyze the contemporary functioning of allotment gardens in Poland based on the example of Tri-City. Thanks to the pilot nature of the study, also including participant observation, a phenomenon of transforming the function of allotment gardens from traditional cultivation to recreation was observed. This phenomenon is particularly dynamic in the area of one of the allotment gardens, which is located in the immediate vicinity of the Gdansk Bay shoreline, in a prestigious location near commercial buildings with tourist, spa and apartment functions. The study undertakes to identify the dynamic process of transforming allotment gardens on the border of Gdansk and Sopot and to estimate the scale of the phenomenon related to the construction of garden houses with residential functions, as well as its social perception. A hypothesis has been formulated that an attractive, seaside location is conducive to the process of purchasing allotment gardens by users from outside Tri-City who invest in new garden houses so that they can spend their holidays in a relatively cheap way. The traditional cultivation function is then lost, and the process itself may cause social conflicts between traditional users and the new ones who treat the plots only recreationally.

The aim of the article was to examine the functions of allotment gardens in the Tri-City, with particular emphasis on those located in an attractive location, adjacent to prestigious buildings, and to determine how this neighborhood may affect the functioning of gardens and their transformation, including social pressure. They also searched for answers on the social perception of allotment gardens in such locations. The aim of the study was also to identify problems inside the allotment gardens related to the abnormal development related to new housing functions and living in the allotment gardens.

\section{Materials and Methods}

As part of the research on changes in the development of allotment gardens in Tri-City, many different narrow, cartographic and statistical methods were used. A field inventory, qualitative analysis of 
the content of planning and strategic documents, questionnaire research and an in-depth interview were conducted. The sampling frame in the form of the legal and actual users of allotments in Tri-City was unknown, since there is no such common database. Therefore, the survey was not representative. When preparing it, however, there were frequent cases when users of the plots were not their actual owners or tenants, in particular, in areas attractive in terms of nature and location, as in the case of the "ROD Oaza" analyzed here in detail. Despite the lack of representativeness, a significant number of responses from people using allotment gardens in Tri-City were obtained. The survey was conducted on a group of 362 respondents who were recruited through direct contact via the Internet groups' associated gardeners. People answering the questions had access to the online form of the questionnaire.

The in-depth interviews were a free directed conversation conducted by asking seven identical questions. The sample was selected using the snowball method with the knowledge of the random frame presented by the administrator of the "ROD Oaza".

The research was also based on a review of foreign and domestic literature and an analysis of the legal status of allotment gardens in Poland. Allotment gardens were inventoried based on data from the Open Street Map resources, as well as the Polish Allotment Federation-the Pomeranian District in Gdańsk. The Studies on the Conditions and Directions of Development in Gdańsk, Gdynia and Sopot were also helpful [10-12]. Data verification was undertaken during field studies. The effects were illustrated on maps with the use of GIS tools (QGIS 3.4.12 Madeira). Additionally, original photographs were taken showing the analyzed phenomenon.

The methods used in the article allowed obtaining answers to the research questions. However, it should be emphasized that the applied methods used also have their limitations. Firstly, the survey, although numerous and addressed to the owners of allotment gardens in Tri-City, was not representative. In-depth interviews were conducted with long-time owners of allotment gardens, but interviews with owners of allotments that are used for recreation would also be valuable. Unfortunately, the Authors could not reach such persons, and they intend to take up this issue in their future research.

\section{Scientific Background}

\subsection{Review of Research on Allotment Gardens}

Allotment gardens, due to their 150-year history, are of interest to researchers in many fields of science. Scientific studies include spatial, economic and environmental aspects of the functioning of allotment gardens. The changing role of allotment plots, from typical cultivation, which, especially in industrial centers, allowed avoiding the problem of food shortages, to the modern function related to recreation, allows for various analyses aimed at showing the importance of allotment gardens for the local community, plot owners or the local government.

Interesting results on gardens were presented in an article by Bell et al. [13], in which the relationship between having a garden and the health condition was discussed. The study was conducted on a representative group of the British population and it showed that having a garden contributed to the respondents' well-being. People who worked in the garden as well as used it for leisure also reported better well-being. The researchers emphasized that in spatial planning, one should bear home gardens and allotment gardens in mind because they affect the health of city residents. Berg et al. [14] conducted a similar study of issues related to the comparison of people who had and did not have allotment gardens. Additionally, in this article, the authors emphasized the potential contribution of allotment gardens to a healthy and active lifestyle, especially in relation to the elderly. The study compared the health, well-being and physical activity of older and younger users of allotment plots with a control group that did not have an allotment garden. The entire group of allotment garden users reported a higher level of physical activity in the summer than their non-gardening neighbors in the respective age categories. Better health was declared in the case of older allotment holders than in the case of 
people who did not have a garden. Similarly, researchers also commented on well-being connected with having allotment gardens in an article devoted to Portugal [15]. Pitkänen et al. [16] wrote about the well-being of owners of "second homes". Having an allotment garden with a house with residential functions in an area that is attractive in terms of nature and location can be considered a similar phenomenon. Costa [17] discussed the functions of allotment gardens in Germany in a similar vein.

The importance of home gardens and allotment gardens was examined in the article by Drescher et al. [18], in which the authors emphasized the importance of both types of gardening. They also stressed that allotment gardens require political intervention in order to secure the land for developing them. Dzikowska et al. [19] noted that investment pressure in cities contributes to limiting green areas, including allotment gardens, which have a special role in shaping a sustainable city structure. Bartłomiejski and Kowalewski [20] discussed allotment gardens as an alternative framework for city development according to the Slow City concept. The ideas of allotment gardens and Slow City can coexist, because together they aim to protect and strengthen strong social relations, civic involvement, spending time outdoors by people of all ages in green areas.

An important issue was presented in the article on the productive role of green gardens in Leicester, Great Britain [21]. The authors believe that the process of urbanization has cut off much of the world's population from engaging in food production. Today, there is a renaissance of interest in having allotment gardens in the city, also including the cultivation function. Pourias et al. [22] described the role of allotment gardens in preventing poverty based on the example of peripheral areas of Seville and Paris. They emphasized that allotment gardens make it easy to obtain produce.

In the introduction, the special role of allotment gardens in developing countries has been emphasized. Gagya and Vigvári [23] presented the situation of allotment gardens based on the example of Central and Eastern Europe, where there is a phenomenon of living in such areas.

Similar issues were discussed in the articles concerning Prague [24] and Brno [25]. In the former, the authors remind the reader that the allotment gardens were created based on the political and ecological process of urbanization of nature, dictated by the communist authorities in 1948-1989, and later by neo-liberal governments. The study compared contemporary urbanization with its socialist predecessor in the context of the role of allotment gardens in the city. In the article about Brno, the authors introduced the concept of hybrid space with reference to allotment gardens in cities. They argued that it is an emanation of a village within a city. The author of the work regarding Gdańsk speaks in a similar vein [26]. Rusanov [2] described the phenomenon of allotment gardens as well as "second homes" in Europe, with a particular emphasis on Central and Eastern Europe. He underlined that in the mid-20th century, the popularity of gardens decreased due to the lack of food shortages, but since the end of the 20th century, it has been growing again due to environmental aspects and the awareness of a healthy lifestyle.

\subsection{Conceptualization of the Idea and Records of the Functions of Allotment Gardens in Poland}

Allotment gardens in cities are not a new phenomenon. The idea of having one's own allotment plot in urban space comes from Great Britain and Germany [27]. Kimic [28] gives examples of their formation already at the turn of the 19th and 20th centuries in support of improving the living conditions of the working class. One of the first allotment gardens was founded by the Allotment Garden Society in Leipzig (Germany). Its task was to provide recreational areas and land for cultivation so that the situation of poor inhabitants could be improved [29]. Wilczyński [30] made the first attempt to define the phenomenon more precisely in the Polish literature. The researcher defined allotment gardens as an area covering a few or several hectares of fenced-off land that is usually on the outskirts of the city.

The beginning of allotment gardening in Poland can be traced back to the end of the 19th century, when in 1897 one of the oldest sites of this type was created. Thirty years later, the United Society of Allotment Gardens of the Republic of Poland was established. A year later, legal regulations on allotment gardens were passed. Several dozen years later, on 6 May 1981, the law on workers' allotment 
gardens was adopted, which were defined as "an area of agricultural land divided into plots intended for garden crops and used by natural persons, equipped with facilities necessary for gardening and at the same time for recreation of the plot users and other people" [31].

Currently, in accordance with the Act of 13 December 2013 [32], legal regulations in Poland define that allotment gardens "(...) should be understood as a designated area or areas intended for the purposes of family allotment gardens, consisting of plots and the general area serving the common use of allotment gardeners, equipped with garden infrastructure". The act also defines new functions of allotment gardens that complement the traditional ones. Among them, the following were distinguished: "restoring degraded areas to the community and nature", "protection of the environment and nature", "affecting the improvement in ecological conditions of municipalities" and "shaping a healthy human environment" [33].

Since the very beginning, the need to have land for cultivation, shaping social attitudes and cooperation skills among the inhabitants, and additionally space for recreation [29] were determinants of the creation of allotment gardens. The influence of allotment gardens on the improvement in physical and mental health, being closer to nature and the greening of cities was also emphasized [28]. In the 19th and the 20th centuries, allotment gardens became spaces that allowed large masses of the urban population to use air, sun and space, and additionally to obtain fruit and vegetables at a low cost.

\subsection{Case Study-Allotment Garden in Tri-City}

The Tri-City area is usually referred to as three cities connected with each other in spatial and functional terms, located on the Bay of Gdańsk in the Pomeranian Voivodeship in Poland. These are Gdańsk, Sopot and Gdynia. In Tri-City there are 112 areas classified as allotment gardens, taking into account "ROD Oaza", analyzed in this article as two separate parts located in Sopot and in Gdańsk (Figure 1). In addition, seven areas that used to be allotment gardens have been identified, but their function has now disappeared. The total area of allotment gardens in Tri-City is 1210.40 ha (including the former gardens with an area of $25.87 \mathrm{ha}$ ). They constitute approx. $2.92 \%$ of the area of entire Tri-City. Gdańsk has the largest share of allotment gardens in the total area, and Sopot the lowest one. A total of 85 gardens have been identified in Gdańsk, 22 in Gdynia and 5 in Sopot. Most of the allotment gardens are situated in locations favorable to investment, with good access by public and private transport. Allotment gardens associated in the Polish Allotment Federation (PZD) (with abbreviation ROD standing for family allotment gardens) constitute $98.32 \%$ of all the functioning gardens in Tri-City. From among all of the identified allotments, the location of "ROD Oaza" was considered the most valuable. This area is located in the immediate vicinity of the shoreline of the Bay of Gdańsk (at minimum approx. $200 \mathrm{~m}$ from the border of the area to the beach), and at the same time it borders on prestigious areas (hotels, apartment buildings, high-standard office buildings). Therefore, the "Oaza" family allotment gardens can be viewed as an attractive investment area or can be seen as an accommodation base during the holiday season due to their seaside location. In the area of "ROD Oaza", various functions were identified, from traditional ones related to growing fruit and vegetables to modern ones related to recreation (Figures 2 and 3). 


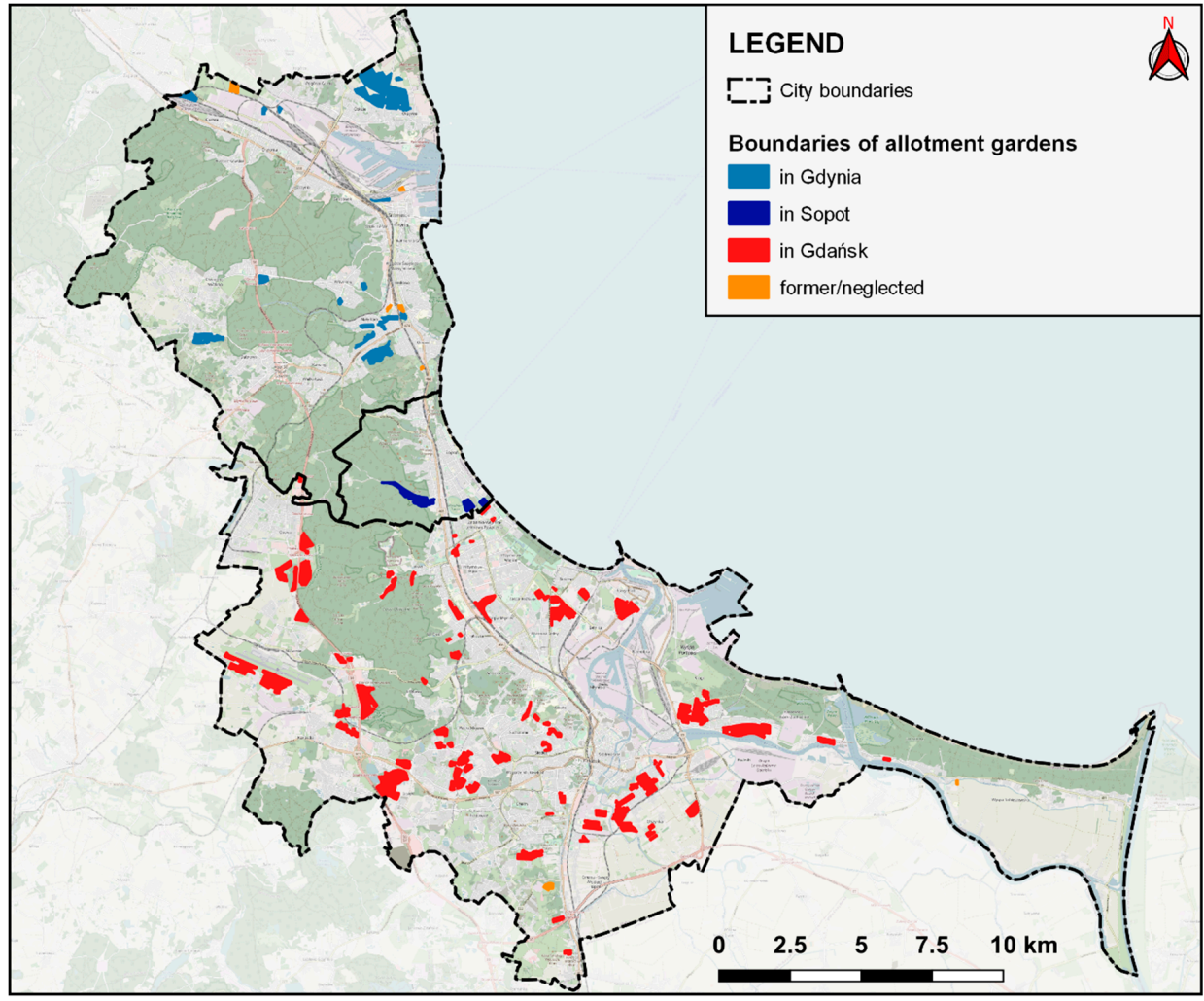

Figure 1. Location of allotment gardens in Tri-City in 2020.

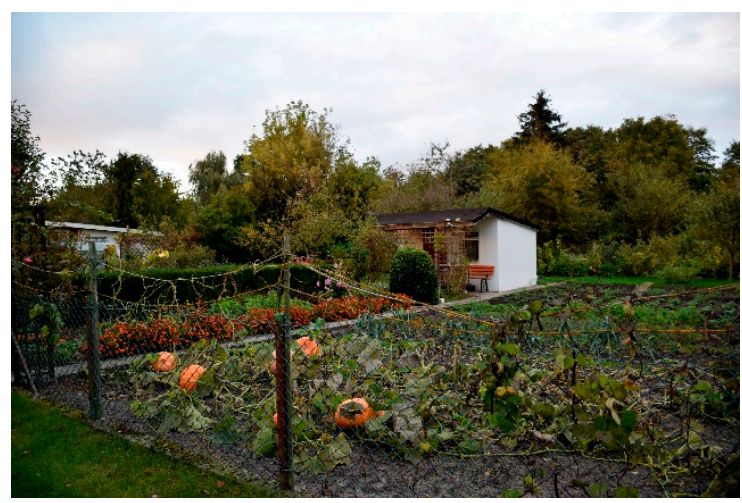

Figure 2. A traditional allotment garden with a small shed for storing tools.

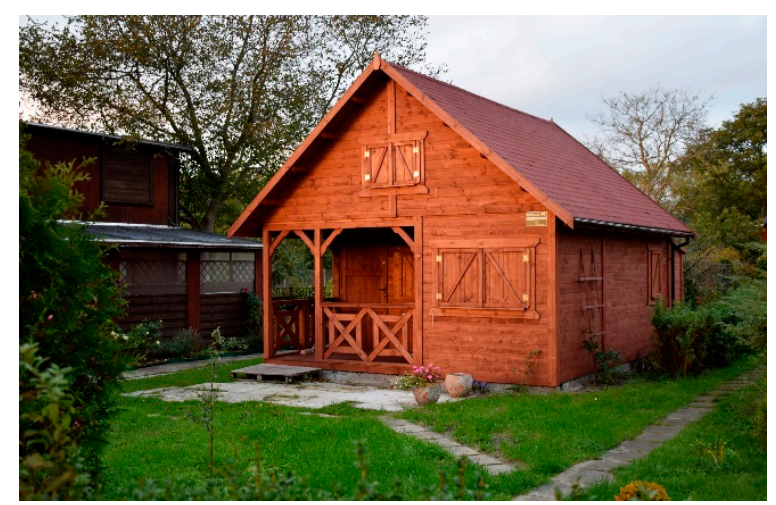

Figure 3. A modern garden house that complies with the regulations for buildings in the garden with a recreational function. 


\subsection{Changes in the Function of Allotment Gardens in Tri-City}

As part of the study, all allotment gardens existing in Tri-City were inventoried. Due to some freedom in the development of allotment gardens, especially in aesthetic and environmental terms, they constitute a specific wealth of users' preferences, but sometimes they give an impression of spatial chaos, disturbing the spatial order of the city. They are often very attractive locations bordering on representative areas or with a high standard of development. According to J. Gehl [33], a well-designed space of allotment gardens encourages one to spend time outdoors. Social relations are created owing to small distances between users and buildings in allotment gardens. Therefore, a desire to have plots of land is not only related to nature, but also to a need to be around people.

Due to the nature of allotment gardens, they may be a subject of dispute, especially in the case of the local authorities' willingness to transform the area into another function. As mentioned, allotment gardens were located peripherally, but as a result of several decades of urbanization, they "came closer to the city", becoming an attractive investment area. In a relatively small area, allotment gardens are cultivated by many people who often create a close community that can unite in its own cause. When analyzing the potential changes in the functions of allotment gardens in Tri-City, several types of problems related to their functioning emerging in the public discourse were identified (cf. Table 1).

Table 1. Selected problems of allotment gardening in Tri-City.

\begin{tabular}{|c|c|c|}
\hline Issues & & Description of Sample Problems \\
\hline Conflicts between garden holders & $\begin{array}{l}1 . \\
2 .\end{array}$ & $\begin{array}{l}\text { Allotment holders who do not use their plots as places of residence are } \\
\text { dissatisfied with being neighbors with those residing in their plots. } \\
\text { Conflicts between allotment holders maintaining a traditional vegetable garden } \\
\text { function and people who treat allotment gardens only as a recreation and } \\
\text { leisure area. }\end{array}$ \\
\hline Non-compliance with the law & 2. & $\begin{array}{l}\text { The Gdańsk City Hall registered the residence of } 102 \text { people in one of the } \\
\text { allotment gardens under the pressure of sentences of administrative courts } \\
\text { regarding the population registration. } \\
\text { The Gdynia City Hall registers residents of one of the allotment gardens due to } \\
\text { acquisitive prescription (often over thirty years' long) [34]. } \\
\text { People illegally residing in allotment gardens do not pay taxes corresponding to } \\
\text { living in houses and apartments [34]. }\end{array}$ \\
\hline $\begin{array}{l}\text { Failure to comply with } \\
\text { the regulations of the Family } \\
\text { Allotment Gardens }\end{array}$ & 2. & $\begin{array}{l}\text { In one of the allotment gardens in Gdańsk, one holder counted approx. } \\
140 \text { permanent (year-round) residents. According to the regulations, } \\
\text { overnight stays in allotment gardens are not allowed [34]. } \\
\text { People who treat allotment gardens as a place of recreation often stay in their area } \\
\text { after the regular time, participate in loud social meetings and organize, } \\
\text { for example, bonfires, which is prohibited throughout most of the year [34]. }\end{array}$ \\
\hline
\end{tabular}


Table 1. Cont.

\begin{tabular}{|c|c|}
\hline Issues & Description of Sample Problems \\
\hline $\begin{array}{l}\text { Unauthorized construction } \\
\text { (oversized buildings) }\end{array}$ & $\begin{array}{l}\text { 1. A garden holder in "ROD Jasien" in Gdańsk believes that the problems } \\
\text { with unauthorized construction result from unsuitable legal regulations. } \\
\text { The Management Board of the Polish Allotment Federation does not } \\
\text { support the construction of oversized buildings and warns against the } \\
\text { purchase of this type of real estate [43]. } \\
\text { 3. The Poviat Inspectorate of Building Supervision is reluctant to deal with } \\
\text { the problem of non-normal buildings in allotment gardens because it } \\
\text { believes that the problem concerns the whole of Poland and should be } \\
\text { solved jointly [34]. }\end{array}$ \\
\hline $\begin{array}{l}\text { The phenomenon of } \\
\text { "second homes" }\end{array}$ & $\begin{array}{l}\text { 1. The attractive location of the allotment gardens in the coastal strip of } \\
\text { Gdańsk and Sopot is conducive to the phenomenon of "second homes" } \\
\text { and the 24-h presence of residents or tourists in allotment gardens in the } \\
\text { summer season [43]. }\end{array}$ \\
\hline Change of the function & $\begin{array}{l}\text { 1. Changing the function of allotment gardens into city parks (e.g., } \\
\text { Reagan's Park in Gdańsk) [36,44-46]. } \\
\text { 2. The Polish Allotment Federation does not defend the change of } \\
\text { allotment gardens to other functions (e.g., the seaside park in Gdańsk, } \\
\text { office buildings in Sopot) }[47,48] \text {. } \\
\text { Local authorities want to acquire land for new investments, including } \\
\text { social ones, e.g., roads, trams lines, residential and service buildings, } \\
\text { and offer to move the gardens to peripheral areas. Older plot users are } \\
\text { unable to get to the new locations. [34,47,49-52]. }\end{array}$ \\
\hline
\end{tabular}

\section{Results}

As part of the research, an attempt was made to thoroughly analyze the functioning of "ROD Oaza" allotment gardens located in a prestigious location on the border of Gdańsk-Jelitkowo and Sopot in the immediate vicinity of apartment buildings and service buildings, including tourist and spa functions (hotels, guesthouses). The pilot studies conducted in previous years had shown that in the area of "ROD Oaza" there might be a change of the traditional function related to growing vegetables and fruit towards the recreational function. Additionally, this process might be much more dynamic than in the case of other locations, because some plot owners invest in new garden houses with typical residential facilities in order to rent them during the holiday season.

\section{1. "ROD Oaza" as an Example of Allotment Gardens in a Prestigious Location}

Among all the identified allotment gardens in the Tri-City, the "ROD Oaza" area was considered to have the most prestigious location. The complex of allotment gardens is situated on the border of Gdańsk and Sopot in the immediate vicinity of the coastal zone of the Bay of Gdańsk. It is an area where the following functions can be distinguished: tourist and spa (hotels, guesthouses, camping sites), residential (prestigious apartment estates) and service (modern office buildings of the ERGO insurance group). The allotment area is divided between Gdańsk and Sopot, but the plots are organized within one entity. The "OAZA" Family Allotment Gardens (ROD) occupies the area of 4.55 ha in Gdańsk and 5.64 ha in Sopot. It should be emphasized that these values have decreased in the last several years due to the construction of a retention reservoir and a housing estate on the side of Gdańsk and a pocket park on the side of Sopot (Figure 4). 


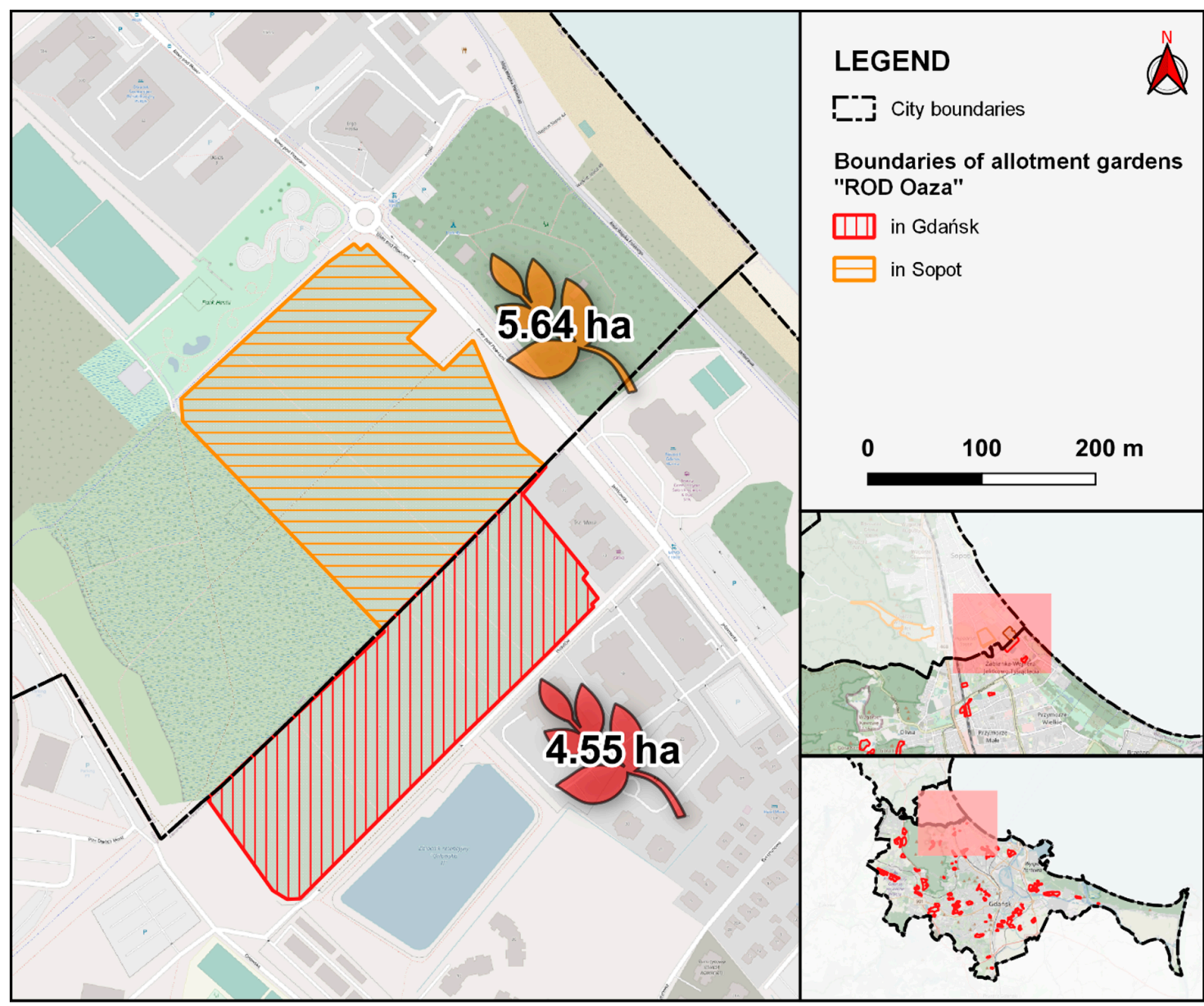

Figure 4. Location of the analyzed "ROD Oaza" allotment gardens on the border of Gdańsk and Sopot in 2020.

The development of "ROD Oaza" is typical of this type of areas. These are small land parcels (from 150 to $600 \mathrm{~m}^{2}$ ) with accompanying garden houses or tool sheds (Figure 5). The area of "ROD Oaza" within the borders of Gdańsk is not covered by any local spatial development plans [53], while the part of Sopot is located on two plots covered by the existing local spatial development plans of Sopot No. R-3/04 and R-3/05 [48]. In the 2019 Study of the Conditions and Directions of the Development of the City of Gdańsk, "ROD Oaza" was not included in the liquidation plans [54].

In the immediate vicinity of "ROD Oaza" from the side of Gdańsk, several housing and service (office) investments have been built in recent years. These are buildings of a high standard, and they are characterized by a high market price. In particular, the fenced-off Botanica apartment estate, separated from "ROD Oaza" by the Orłowska II reservoir, which was built in the area formerly also occupied by these allotment gardens, is one of the most expensive residential locations in entire Tri-City. Office buildings of the international insurance group ERGO are also located in the immediate vicinity of these allotment gardens. 


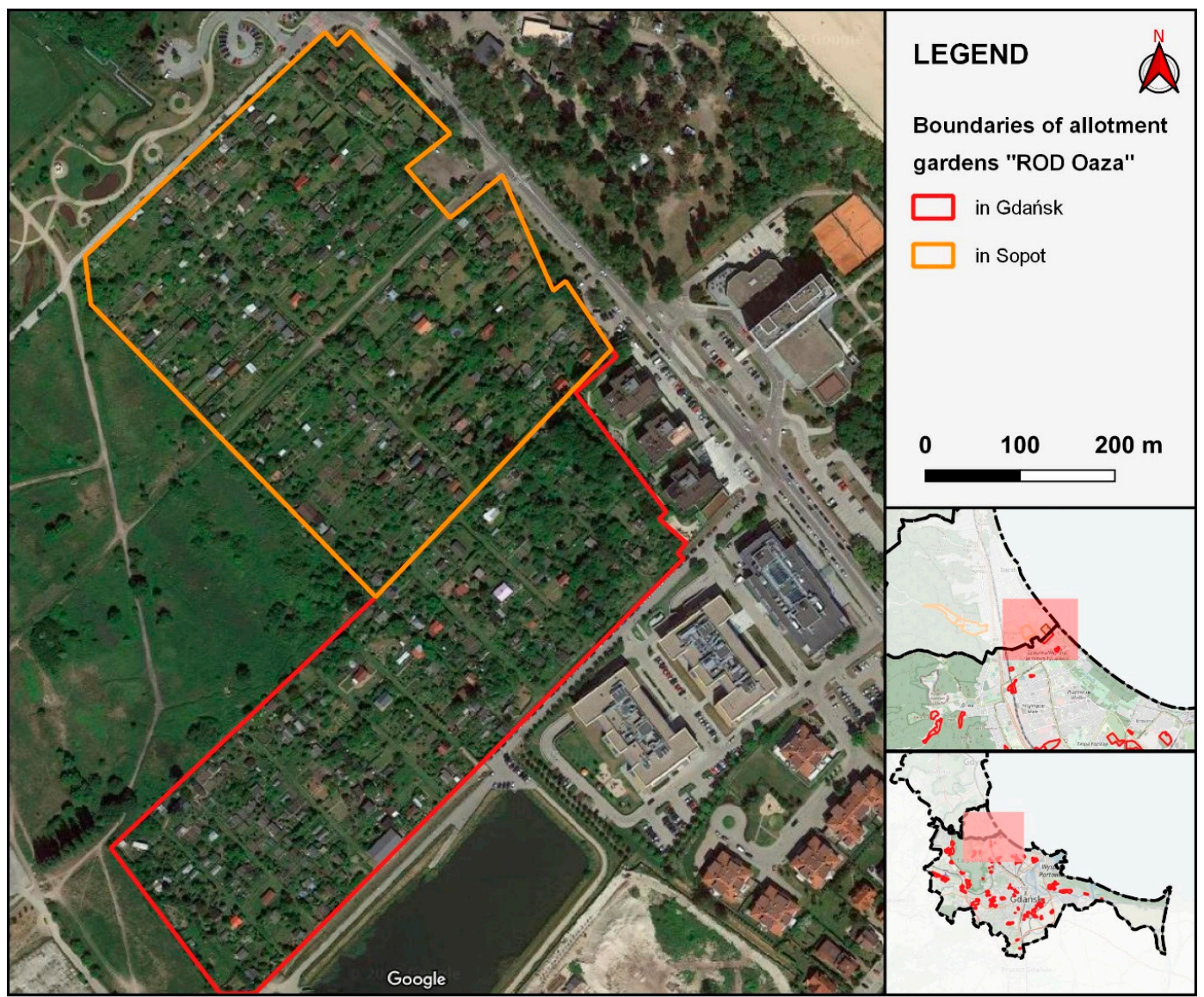

Figure 5. Spatial development of “ROD Oaza" allotment gardens in 2020.

\subsection{Unauthorized Construction}

The Act on Allotment Gardens in Poland stipulates that a garden house can be built on the plot. It can be a detached facility with a recreational and leisure function with the built-up area of up to $35 \mathrm{~m}^{2}$ and height of up to $5 \mathrm{~m}$ with sloping roofs or up to $4 \mathrm{~m}$ with flat roofs, while the built-up area does not include the terrace, veranda or porch, provided that their total area does not exceed $12 \mathrm{~m}^{2}$ [32]. The size of garden houses provided for in the legal regulations is considerable. It gives opportunities to build a comfortable space for recreation, as well as a chance to create a space for everyday life, which often becomes the subject of conflicts with local authorities or other plot owners. In the analyzed area, the phenomenon of unauthorized construction occurs more and more often, especially when new owners of plots build facilities with residential functions, intended for living during the summer holidays. According to the provisions of the studies of the conditions and directions of spatial development in Gdańsk and Sopot, it is illegal to live in allotment gardens. They are intended solely for cultivation and recreation. In addition, the regulations of the Polish Allotment Federation define the hours during which one can stay in allotment gardens associated within the structures of Family Allotment Gardens. The regulations also do not allow the possibility of staying overnight on the plots [55].

In compliance with the legal regulations in force, in allotment gardens in Poland, it is possible to erect non-permanent buildings, without a basement, made of wood, without the septic tank facility. As part of the inventory of the area of "ROD Oaza", many buildings were identified that do not meet the regulations. In particular, the construction of many new brick houses was noted, also often with toilets, and thus also illegal sewage discharge. Some of the houses probably exceed the permissible height and built-up area (cf. Figure 6). 

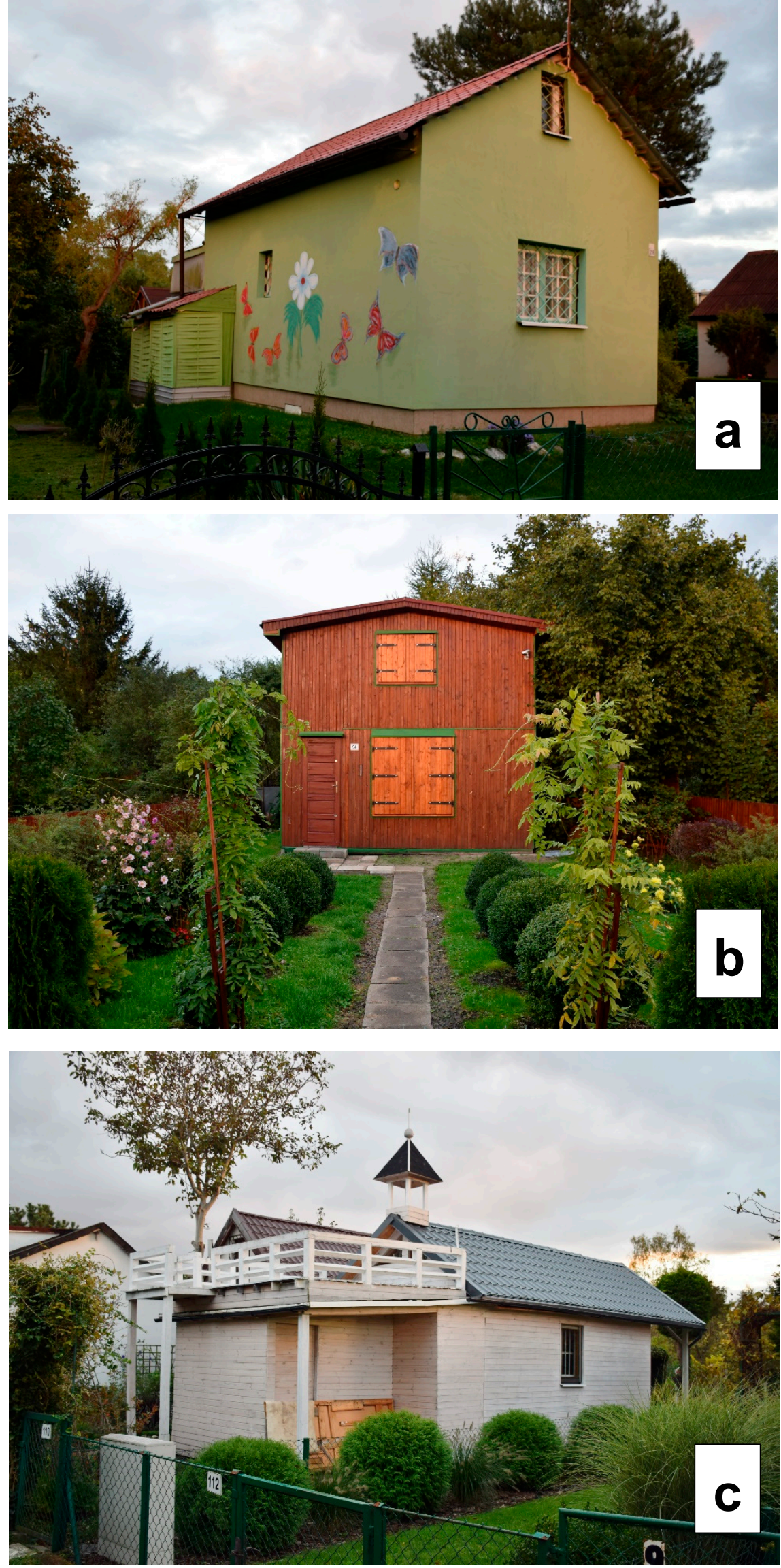

Figure 6. Examples of buildings inconsistent with applicable regulations, exceeding the permissible height $(\mathbf{a}, \mathbf{b})$, building material $(\mathbf{a})$ and built-up area $(\mathbf{c})$. 


\subsection{Surveys on the Perception of Allotment Gardens}

As part of the study on the perception of allotment gardens and changes in their functions and the vicinity of plots with traditional and modern functions, a questionnaire survey was conducted among owners of such plots in Tri-City. The sample is not representative because, as mentioned in the methodological chapter, the sampling frame is unknown. However, a significant number of responses were obtained. The sample was $n=362$. The survey consisted of nine questions, seven of which were closed-ended questions, and two were open-ended questions. The majority of the respondents were women $(70.4 \%)$ aged up to 45 years old, living in cities. A total of $85.4 \%$ of the respondents lived in cities, with less than $25 \%$ of them coming from small towns of up to 20,000 residents, over $29 \%$ from cities with a population of 20,000 to 100,000 inhabitants, and the rest declared living in large cities: from 100,000 to 500,000 inhabitants-24.1\%, and in cities with over 500,000 inhabitants-22.2\%.

The first question, which concerned unauthorized construction in allotment gardens, 30.7\% of the respondents answered in the affirmative; $48.1 \%$ did not encounter such a problem, and $21.3 \%$ were not interested in it.

People who answered "yes" to question 1 had an opportunity to answer the next question: "If you have encountered the problem of unauthorized construction in allotment gardens, please give an example". Out of 111 people declaring knowledge of such an issue, 99 could give an example. Of these, 62 responses related to buildings violating the ROD regulations in terms of surface, and 16 in terms of the height of buildings. There was also information related to the construction of permanent brick or tin grills (five responses). Nine responses concerned the lack of a building permit or construction design. Seven answers were incorrect and unrelated to the question. One of the answers given to this question proved that the respondent knew the subject very well. He/she noted that he/she knew many examples of breaking the ROD regulations in terms of building facilities and thought that the fault lay with a lack of knowledge of these regulations by plot owners. He/she believed that the regulations allowed for construction in such a way that it was possible to have a building with a large surface without breaking the law. Examples were given of houses that were too high or too large. Garden owners also do not distinguish the types of roofs; they exceed the permissible size of the terrace $\left(12 \mathrm{~m}^{2}\right)$; they close up the terrace with walls, thus creating an oversized built-up area, and they do not keep an appropriate distance from their neighbors.

Question 3 asked about examples of non-standard buildings resembling residential houses. 75.1\% of the respondents encountered such examples; $19.9 \%$ answered "no", and 5\% were not interested in this issue.

Question 4 concerned living in a garden house. An amount of $84.7 \%$ of the respondents denied having used such a solution in the past. A total of $14.7 \%$ of the respondents admitted to living in their garden houses during the summer, and $0.6 \%$ admitted to living all year round (two cases).

The next question asked about the knowledge about the statutory provisions of ROD and exceeding the permitted built-up area. Most people (68.8\%) declared familiarity with these regulations, but as many as $24 \%$ of the respondents did not know about the existence of such regulations. The other people showed no interest in the topic.

The next question was related to the conflicts that may be caused by illegal construction in allotment gardens. The vast majority $(77.6 \%)$ confirmed that they had encountered or heard about such problems. The remaining respondents did not encounter such an issue.

Question 7 was open-ended and was addressed to people who confirmed their knowledge of conflicts resulting from illegal construction in the previous question. Out of 281 answers given to the question about an example of this type of conflict, only 63 people were able to specify it. A total of 41 people replied that they could not give an example or did not remember it. The remaining respondents did not answer at all.

In question 8 , the issue of the function of allotment gardens was raised. The respondents had a choice of one of the three functions that, in their opinion, should be dominant in allotment gardens. As many as $88.4 \%$ believed that gardens should primarily play mixed functions (related to cultivation 
and recreation). According to nearly $7 \%$ of the respondents, the dominant function of the plot should be related only to recreation (without cultivation), while $4.7 \%$ of the respondents replied that the dominant role should be cultivation (without recreation).

The last question was related to the issue of permission to live temporarily in allotment gardens. Most of the respondents (56.5\%) believed that such a solution should be allowed, and $24.4 \%$ of the answers were negative. A little over 19\% of respondents did not express an opinion on this subject.

The study shows that the function of allotment gardens has evolved over the last few decades from typical cultivation to the mixed one that combines recreational aspects with obtaining crops. The change of the function is also associated with building new garden houses with extended functions, which may cause conflicts among plot users. Most often, the problem concerns the surface area and the height of the buildings as well as the distance from neighboring buildings. However, most of the respondents believed that it would be appropriate to allow temporary residence in garden houses, e.g., in the summer season.

\subsection{Opinions of the Owners of Traditional Allotment Gardens on Changing Their Functions}

When analyzing "ROD Oaza" in terms of changes in functions, three respondents were selected using the snowball method from the group of long-term users (minimum 20 years) of allotment gardens in this area. The group of potential respondents was indicated by the manager of "ROD Oaza". The study was conducted in the form of a free, directed interview. Three women, aged 62,75 and 89 years old, were interviewed (Table 2). Each respondent received the same set of six questions, and one of the respondents was asked an additional question due to the change in the function of the allotment garden and due to having a new garden house.

The oldest of the respondents has had her plot in "ROD Oaza" since 1998, but since 1962, she has had other plots of land. The dominant function of her plot is cultivation with a slight recreational function. The respondent repeatedly stated that this was a plot of land "for vegetables and flowers". The second respondent has had a plot of land in "ROD Oaza" since 1976 and it was her first and only allotment garden. It is a garden with a typical cultivation function without other functions. She repeatedly called her plot a "vegetable patch". The last of the respondents has a plot with a typically recreational function with a very small cultivation function (mainly flowers, few vegetables). She also has a new garden house with functions typical of a residential house or apartment. She also regularly stays overnight on her plot during the holiday season, despite living permanently in Gdańsk. She has been an active allotment owner for 40 years.

The study shows that allotment gardens are a very important element of life for long-term owners of plots, in particular those who live in the nearby area. They allow being in nature, but also establishing and maintaining social relationships. Allotment gardens allow relaxing, but also obtaining fruit and vegetables grown by oneself. Owners of allotment gardens enjoy them very much. Respondents of the in-depth interview notice the changes taking place in "ROD Oaza", which are a consequence of its attractive location by the sea, which makes them an attractive place to rest and sometimes to live in during summer holidays. New garden houses are not a problem for them, provided that they have been built in accordance with applicable regulations and are not used for profit-making (rent). All three respondents are moderately or significantly afraid of losing their allotment gardens and designating the land for other purposes. Due to their age, they would not be willing to move their gardens to another peripheral place of Gdańsk or Sopot. 
Table 2. Answers given in the in-depth interview.

\begin{tabular}{|c|c|c|c|c|}
\hline & Question & Respondent I (89 Years Old) & Respondent II (75 Years Old) & Respondent III (62 Years Old) \\
\hline 1 & $\begin{array}{l}\text { Changes in the functions of } \\
\text { allotment gardens }\end{array}$ & $\begin{array}{l}\text { yes, she notices them } \\
\text { the short lease period is a big problem } \\
\text { according to her, if the lease period was more } \\
\text { permanent, users would be willing to invest in } \\
\text { improving the aesthetics and development }\end{array}$ & $\begin{array}{l}\text { - } \quad \text { yes, unfortunately she notices them } \\
\text { tourist function, due to the attractive location } \\
\text { by the sea } \\
\text { she believes that people mainly come from } \\
\text { outside Tri-City }\end{array}$ & $\begin{array}{l}\text { she believes that there are half of those in favor } \\
\text { of typical cultivation and half in favor of } \\
\text { the recreational function }\end{array}$ \\
\hline 2 & $\begin{array}{l}\text { Change of plot owners (older or } \\
\text { younger people) }\end{array}$ & $\begin{array}{ll}- & \text { rather older } \\
- & \text { local residents } \\
\text { - } & \text { attractive, close location for residents of } \\
& \text { nearby housing estates }\end{array}$ & $\begin{array}{l}\text { - } \quad \text { rather elderly people, retired or on } \\
\text { a disability pension } \\
\text { less often younger people }\end{array}$ & $\begin{array}{l}\text { she believes that many young people have } \\
\text { been buying allotments in recent years }\end{array}$ \\
\hline 3 & $\begin{array}{l}\text { Opinion on new large garden } \\
\text { houses with residential } \\
\text { functions }\end{array}$ & $\begin{array}{l}\text { she does not mind new houses and even } \\
\text { thinks it is good that they are built } \\
\text { she believes, however, that they should } \\
\text { comply with the regulations }\end{array}$ & $\begin{array}{l}\text { due to the lack of such garden houses in her } \\
\text { neighborhood, she does not mind } \\
\text { she adds, however, that she is generally } \\
\text { against them }\end{array}$ & $\begin{array}{l}\text { new garden houses do not bother her, } \\
\text { provided that they comply with the rules } \\
\text { and regulations } \\
\text { she believes that some garden holders build } \\
\text { new houses for rent during the holiday season }\end{array}$ \\
\hline 4 & $\begin{array}{l}\text { Fear that the plot will be taken } \\
\text { away by the local government } \\
\text { for other investments }\end{array}$ & $\begin{array}{l}\text { - yes, she is afraid of that } \\
\text { - } \quad \text { she believes that the location of "ROD Oaza" } \\
\text { is an attractive one, and therefore, plots are } \\
\text { at risk } \\
\text { for her, the allotment garden also means } \\
\text { many friendships }\end{array}$ & $\begin{array}{l}\text { - } \quad \text { because of her age, she is not afraid } \\
\text { she believes that the plots will be taken away } \\
\text { due to their attractive location } \\
\text { she believes that this is not a good trend }\end{array}$ & $\begin{array}{l}\text { - yes, she is afraid all the time; she believes that } \\
\text { the allotment plots are in danger of being } \\
\text { taken away for new investments } \\
\text { it is important to her to maintain } \\
\text { long-term friendships }\end{array}$ \\
\hline 5 & $\begin{array}{l}\text { Feelings accompanying } \\
\text { allotment owners on whether it } \\
\text { is still an allotment garden or } \\
\text { rather a housing estate }\end{array}$ & $\begin{array}{l}\text { - she believes that these are more traditional } \\
\text { allotment gardens }\end{array}$ & $\begin{array}{l}\text { she believes that they are still traditional } \\
\text { allotment gardens despite some overly large } \\
\text { garden houses or the recreational function }\end{array}$ & $\begin{array}{l}\text { her opinion is balanced; she believes that they } \\
\text { are still traditional allotment gardens, } \\
\text { but some new houses destroy this landscape }\end{array}$ \\
\hline 6 & $\begin{array}{l}\text { Is there any discussion on land } \\
\text { development? }\end{array}$ & $\begin{array}{l}\text { yes, there are discussions to make garden } \\
\text { houses esthetic, placed in one row to reduce } \\
\text { the chaos of development }\end{array}$ & - $\quad$ she has not heard of such a discussion & $\begin{array}{l}\text { she participated in such meetings of garden } \\
\text { owners; she knows about the preparation of } \\
\text { a development plan }\end{array}$ \\
\hline 7 & $\begin{array}{l}\text { Is having a new large garden } \\
\text { house associated } \\
\text { with difficulties }\end{array}$ & $\mathrm{n} / \mathrm{a}$ & $\mathrm{n} / \mathrm{a}$ & $\begin{array}{l}\text { she does not pay any additional fees for this } \\
\text { and does not experience any } \\
\text { additional problems }\end{array}$ \\
\hline
\end{tabular}




\section{Discussion and Conclusions}

The article attempts to define the processes and phenomena occurring in the functioning of allotment gardens based on the example of Tri-City in Poland. One of the allotment gardens was thoroughly analyzed, which was defined as situated in an attractive location, in the immediate vicinity of the shoreline of the Bay of Gdańsk. Thanks to the pilot studies conducted in previous years and in particular the participant observation, it was noticed that the process of changes in the area of "ROD Oaza" is particularly extensive and may be associated with an attractive, seaside location. Due to their location, these gardens are exposed to various phenomena that do not occur on a large scale in other locations. In particular, there are many investments related to the construction of new garden houses, often exceeding the legal dimensions. It has been proven that this is a process related to the desire to earn money through seasonal rentals for tourists from outside Tri-City. In fact, it is an activity prohibited by both the Act on Allotment Gardens and the regulations of the Polish Allotment Federation, but it is not prosecuted by any institution $[55,56]$. Garden houses often resemble normal apartments in their function and aesthetics, although they should not have, for example, sewage systems [57]. In addition, it is not allowed to stay overnight in Family Allotment Gardens.

In order to achieve the presented goals and prove the thesis, field studies, surveys addressed to the owners of allotment gardens in Tri-City as well as in-depth interviews with long-term owners of allotments in the area of "ROD Oaza" were conducted. The survey highlighted the perception of allotment gardens by their owners, and in particular revealed the changing functions. Historically, allotment gardens functioned in order to obtain fruit and vegetable crops. Today, the mixed function dominates. The recreational and leisure components are both important. Nearly $60 \%$ of the surveyed respondents believe that seasonal occupation of allotment gardens should be allowed if their owners wish to do so. Most of the respondents also encountered oversized buildings in allotment gardens. A significant share of the respondents also believes that the applicable regulations should be observed. Additional information on this subject was presented in an in-depth interview with three owners of plots in the area of "ROD Oaza". Two of them have gardens for cultivation, and one for recreation. However, none of them are obviously disturbed by the change of the function of allotments, as long as they meet all legal regulations. Seasonality in the area of "ROD Oaza" is noticeable due to its attractive location. During the holiday season, people from outside Tri-City come, probably to rent garden houses or they are their so-called "second homes" (cf. $[2,13,16])$. For the existing owners of allotment gardens, a greater problem is the threat of changing their functions, taking away allotment gardens by the local government due to its attractive location and the vicinity of prestigious housing estates and service buildings with tourist and office functions [13].

The article analyzes the allotment gardens affected by economic factors and by modernization of cities [9]. On the one hand, the inhabitants are more affluent and do not need a garden allowing them to obtain fruit and vegetables close to their place of residence, and at the same time they want the allotment gardens to be more aesthetically pleasing. Hence, the grass-roots modernization is taking place, which consists of changing the function and building garden houses with residential functions. However, the observed process is illegal at least to some extent. There is a lack of adequate regulations and, above all, their enforcement. The survey showed that the vast majority of allotment holders believe that the mixed function should dominate in allotment gardens, and that temporary residence should be allowed if the owners wish it. It was indicated in the analyzed area that despite the fact that the allotment gardens are located in a prestigious area, they do not generate very large neighborhood problems. Internal changes, especially those concerning functions, also do not cause very strong conflicts. It is important because the social pressure on the aestheticization of urban space is very high. Keeping allotment gardens close to where they live is important to their owners, but does not necessarily fit in with the city's development plans. In Gdańsk and Sopot, the functions of allotment gardens in the seaside zone were maintained, even though all the free construction plots around are built up with new hotels, guesthouses and apartment buildings. The classic functions of allotments still coexist with the new ones. This is a process similar to that in other European 
countries [1-3,9,13-18]. So far, allotment gardens in the Tri-City have been moved from their previous locations to new, less prestigious ones, as was the case in other countries $[2,17,18,24,25]$. Despite this, the analyzed allotments were left, the aesthetics of which are taken care of by the managers, so as to limit the number of conflicts generated by them.

The article concerned the study of changes in the functions of allotment gardens in the Tri-City, with the example of a garden located in an attractive location and neighborhood. The study was planned and most of it was conducted before the outbreak of SARS-CoV-2 in Poland, but the extraordinary situation provoked by the Covid-19 disease paradoxically opens up new research fields for allotment gardens. Restrictions on daily activities such as practicing sports, using shopping malls, attending cultural sites such as museums, cinemas, theaters, may have resulted in an increased interest in having an allotment garden. In subsequent studies, it is worth taking up this topic and examining to what extent the epidemic situation influenced the change in the approach to allotment gardens, and the information presented in this article may constitute a good comparative basis.

Author Contributions: Conceptualization, Ż.M., K.P. and M.P.; methodology, Ż.M., M.P.; software, Ż.M.; validation, Ż.M. and M.P.; formal analysis, Ż.M.; investigation, M.P.; resources, Ż.M., K.P. and M.P.; data curation, Ż.M.; writing—original draft preparation, Ż.M., M.P. and K.P.; writing—review and editing, K.P., M.P.; visualization, Ż.M.; supervision, K.P., M.P.; funding acquisition, M.P. All authors have read and agreed to the published version of the manuscript.

Funding: The research received no external funding.

Conflicts of Interest: The authors declare no conflict of interest.

\section{References}

1. Keshavarz, N.; Bell, S. A history of urban gardens in Europe. In Urban Allotment Gardens in Europe; Bell, S., Fox-Kämper, R., Keshavarz, N., Benson, M., Caputo, S., Noori, S., Voigt, A., Eds.; Routledge: New York, NY, USA, 2016; pp. 8-32.

2. Rusanov, A. Dacha dwellers and gardeners: Garden plots and second homes in Europe and Russia. Popul. Econ. 2019, 3, 107-124. [CrossRef]

3. Grebler, L. Urban Renewal in European Countries. J. Am. Inst. Plan. 1962, 28, 229-238. [CrossRef]

4. Camerin, F. From "Ribera Plan" to "Diagonal Mar", passing through 1992 "Vila Olímpica". How urban renewal took place as urban regeneration in Poblenou district (Barcelona). Land Use Policy 2019, 89, 104226. [CrossRef]

5. Álvarez Mora, A.; Camerin, F. La herencia del urban renewal en los procesos actuales de regeneración urbana: El recorrido Renovación-Regeneración a debate. Ciudad Territ. Estud. Territ. (CYTET) 2019, 51, 5-26.

6. Lees, L.; Phillips, M. (Eds.) Handbook of Gentrification Studies; Edward Elgar Publishing: Glos, UK, 2018.

7. Lefebvre, H. Le Droit à la Ville; Anthropos: Paris, France, 1968.

8. Sklair, L. The Icon Project: Architecture, Cities, and Capitalist Globalization; Oxford University Press: Oxford, UK, 2017.

9. Bellows, A. One hundred years of allotment gardens in Poland. Food Foodways 2004, 12, 247-276. [CrossRef]

10. Studium Uwarunkowań i Kierunków Zagospodarowania Przestrzennego (SUiKZP) Miasta Gdańska. 2019. Available online: https://www.brg.gda.pl/planowanie-przestrzenne/studium-uwarunkowan-i-kierunkowzagospodarowania-przestrzennego (accessed on 27 April 2020).

11. Studium Uwarunkowań i Kierunków Zagospodarowania Przestrzennego (SUiKZP) Gdyni. 2019. Available online: https://bip.um.gdynia.pl/studium-uwarunkowan-i-kierunkow-zagospodarowania-przestrzennego-gdyni,425/ studium-uwarunkowan-i-kierunkow-zagospodarowania-przestrzennego-gdyni,383263 (accessed on 3 May 2020).

12. Studium Uwarunkowań i Kierunków Zagospodarowania Przestrzennego (SUiKZP) Miasta Sopotu. 2018. Available online: https://bip.sopot.pl/m,183,studium-uwarunkowan-i-kierunkow-zagospodarowaniaprzestrzennego.html (accessed on 4 May 2020).

13. Bell, S.; White, M.; Griffiths, A.; Darlow, A.; Taylor, T.; Wheeler, B.; Lovell, R. Spending time in the garden is positively associated with health and wellbeing: Results from a national survey in England. Landsc. Urban Plan. 2020, 200, 103836. [CrossRef] 
14. Van der Berg, A.; van Winsum-Westra, M.; de Vries, S.; van Dillen, S. Allotment gardening and health: A comparative survey among allotment gardeners and their neighbors without an allotment. Environ. Health 2010, 9, 74. [CrossRef] [PubMed]

15. Mourão, I.; Moreira, M.; Almeida, T.; Brito, L. Perceived changes in well-being and happiness with gardening in urban organic allotments in Portugal. Int. J. Sustain. Dev. World Ecol. 2019, 26, 79-89. [CrossRef]

16. Pitkänen, K.; Lehtimäki, J.; Puhakka, R. How do Rural Second Homes Affect Human Health and Well-being? Review of Potential Impacts. Int. J. Environ. Res. Public Health 2020, 17, 6748. [CrossRef]

17. Costa, C. Kleingärten-Um componente da infraestrutura urbana: Aspectos urbanísticos, ecológicos e sociais dos jardins arrendados na Alemanha. Urbe Rev. Bras. Gestão Urbana (Braz. J. Urban Manag.) 2012, 4, $103-122$. [CrossRef]

18. Drescher, A.; Holmer, R.; Iaquinta, D. Urban Homegardens and Allotment Gardens for Sustainable Livelihoods: Management Strategies and Institutional Environments. In Tropical Homegardens: A Time Tested Example of Sustainability; Nair, P., Kumar, B., Eds.; Springer: Cham, Switzerland, 2006; pp. 317-338.

19. Dzikowska, A.; Krzemińska, A.; Zareba, A. Allotment Gardens as Significant Element Integrating Greenery System of the City. IOP Conf. Ser. Earth Environ. Sci. 2019, 221, 012121. [CrossRef]

20. Bartłomiejski, R.; Kowalewski, M. Polish Urban Allotment Gardens as 'Slow City' Enclaves. Sustainability 2019, 11, 3228. [CrossRef]

21. Edmondson, J.; Childs, D.; Dobson, M.; Gaston, K.; Warren, P.; Leake, J. Feeding a city—Leicester as a case study of the importance of allotments for horticultural production in the UK. Sci. Total Environ. 2020, 705, 135930. [CrossRef] [PubMed]

22. Pourias, J.; Asuero, R.; Aubry, C.; Ducrocq, T.; Zarandieta, J. Urban Associative Gardens in Poor Neighbourhoods of Seville and Paris: Garden Productions and Access to Food; Foundation Carrefour: Massy, France, 2020.

23. Gagyi, Á.; Vigvári, A. Informal Practices in Housing Financialisation: The Transformation of an Allotment Garden in Hungary. Crit. Hous. Anal. 2018, 5, 46-55. [CrossRef]

24. Gibas, P.; Boumová, I. The Urbanization of Nature in a (Post) Socialist Metropolis: An Urban Political Ecology of Allotment Gardening. Int. J. Urban Reg. Res. 2020, 44, 18-37. [CrossRef]

25. Sovová, L.; Krylová, R. The countryside in the city? Rural-urban dynamics in allotment gardens in Brno, Czech Rupublic. Morav. Geogr. Rep. 2019, 27, 108-121.

26. Jelińska, A. Rodzinne ogrody działkowe-Mikroświat w mieście. Analiza zjawiska na przykładzie Gdańska. In Człowiek i Miasto: Gdańszczanie Między Stara a Nowa Tożsamościa; Dymarski, Z., Ed.; Wydawnictwo Uniwersytetu Gdańskiego: Gdańsk, Poland, 2017; pp. 121-141.

27. Dymek, D.; Bednorz, W. Zagospodarowanie rodzinnych ogrodów działkowych (ROD) na przykładzie ROD im. Józefa Chociszewskiego w Poznaniu. Studia Miej. 2017, 25, 133-147. [CrossRef]

28. Kimic, K. Ogródki dla robotników przełomu XIX i XX wieku-Założenia ideowe dla rozwiązań stosowanych w Królestwie Polskim. Czas. Techniczne. Archit. 2012, 8, 171-178.

29. Pawlikowska-Piechotka, A. Ogrody działkowe w rozwoju zrównoważonym współczesnego miasta. Probl. Ekol. 2009, 13, 106-109.

30. Wilczyński, S. Ogródki Działkowe Jako Zagadnienie Społeczne; Okręgowy Związek Kas Chorych w Krakowie: Kraków, Poland, 1931.

31. Ustawa z Dnia 6 Maja 1981 r. o Pracowniczych Ogrodach Działkowych. Available online: http://prawo.sejm. gov.pl/isap.nsf/download.xsp/WDU19810120058/U/D19810058Lj.pdf (accessed on 29 May 2020).

32. Ustawa z Dnia 13 Grudnia 2013 r. o Rodzinnych Ogrodach Działkowych. Available online: http://prawo. sejm.gov.pl/isap.nsf/download.xsp/WDU20140000040/U/D20140040Lj.pdf (accessed on 18 June 2020).

33. Gehl, J. Three types of outdoor activities and life between building. In The Urban Design Reader; Larice, M., Macdonald, E., Eds.; Routledge: Abingdon, UK, 2012; pp. 264-370.

34. Lange, M. Mieszkańcy Ogródków w Redłowie Chcą Pozostać na Tym Terenie. Available online: https://gdynia. naszemiasto.pl/mieszkancy-ogrodkow-w-redlowie-chca-pozostac-na-tym-terenie/ar/c8-3813548 (accessed on 17 May 2020).

35. MPZP Terenu Ogródków Działkowych Przy alei Zwycięstwa 136 w Gdyni (nr 1402). 2003. Available online: https://static.um.gdynia.pl/storage/_old/gdynia.pl//g2/2007_01/4997_filebig.jpg (accessed on 3 June 2020).

36. Szadurski, S. Działki w Ręce Miasta. 2008. Available online: https://dziennikbaltycki.pl/dzialki-w-recemiasta/ar/31975 (accessed on 26 April 2020). 
37. Szadurski, S. Gdynia Przejmuje Działki Stokrotka Przy al. Zwycięstwa. Działkowcy Dostaną Tereny i Rekompensaty. 2009. Available online: https:/gdynia.naszemiasto.pl/gdynia-przejmuje-dzialki-stokrotkaprzy-al-zwyciestwa/ar/c8-16319 (accessed on 17 May 2020).

38. Szadurski, S. Członkowie Stowarzyszenia “My tu mieszkamy” nie Zostaną Wysiedleni z Redłowa. 2010. Available online: https://gdynia.naszemiasto.pl/czlonkowie-stowarzyszenia-quotmy-tu-mieszkamyquotnie/ar/c1-322342 (accessed on 17 May 2020).

39. Szadurski, S. Konflikt Władz Gdyni z Mieszkańcami Działek Przy Alei Zwycięstwa Zażegnany. 2010. Available online: https://gdynia.naszemiasto.pl/konflikt-wladz-gdyni-z-mieszkancami-dzialek-przy-alei/ar/ c1-322060 (accessed on 17 May 2020).

40. Szadurski, S. Zwycięstwo Gdynian z Alei Zwycięstwa. 2010. Available online: https://gdynia.naszemiasto. pl/zwyciestwo-gdynian-z-alei-zwyciestwa/ar/c1-407952 (accessed on 4 May 2020).

41. Szadurski, S. Konflikt w Gdyni. Urzędnicy Chca Przenieść Ogródki Działkowe na Peryferia Miasta. 2014. Available online: https://dziennikbaltycki.pl/konflikt-w-gdyni-urzednicy-chca-przeniesc-ogrodkidzialkowe-na-peryferia-miasta/ar/3329303 (accessed on 17 May 2020).

42. Szadurski, S. W Gdyni Ważą się Losy Terenów Dawnych Ogródków Działkowych Przy al. Zwycięstwa. 2017. Available online: https://gdynia.naszemiasto.pl/w-gdyni-waza-sie-losy-terenow-dawnych-ogrodkowdzialkowych/ar/c8-4180798 (accessed on 17 May 2020).

43. Katka, K. Na działkach Rosną Wille. Gdzie? W Atrakcyjnej Części Gdańska. Available online: https://trojmiasto.wyborcza.pl/trojmiasto/1,35612,16621004,Na_dzialkach_rosna_wille_Gdzie_W_ atrakcyjnej_czesci.html?disableRedirects=true (accessed on 20 May 2020).

44. Gawlik, N. Gdańsk ma Piękny Park, Którego Wszyscy Zazdroszczą. Available online: https://www.gdansk. pl/wiadomosci/urzednicy-Z-rumii-z-wizyta-w-parku-regana,a,107138 (accessed on 20 May 2020).

45. Milianowska, B.; Matwies, J. Park Nadmorski im. Ronalda Reagana Jako Jedna z Największych Gdańskich Inwestycji, Którą Zawdzięczamy Prezydentowi Adamowiczowi. Available online: http://www.pzdgdansk.pl/aktualnosc/2039-park-nadmorski-im-ronalda-reagana-jako-jedna-znajwiekszych-gdanskich-inwestycji-ktora-zawdzieczamy-prezydentowi-adamowiczowi (accessed on 17 June 2020).

46. Sielski, M. Gdynia: Działki Znikaja, Powstaną Mieszkania. 2012. Available online: https://www.trojmiasto. pl/wiadomosci/Gdynia-dzialki-znikaja-powstana-mieszkania-n60385.html (accessed on 17 June 2020).

47. Naskręt, M. Spór o Przeniesienie aż 500 ha Działek Ogrodowych w Gdańsku. Działkowcy nie Chca Przeprowadzać się do Sobieszewa. 2019. Available online: https://m.radiogdansk. pl/wiadomosci/item/101368-spor-o-przeniesienie-az-500-ha-dzialek-ogrodowych-w-gdanskudzialkowcy-nie-chca-przeprowadzac-sie-do-sobieszewa?fbclid=IwAR0pEP9gHyy7jSKWmm_ 56yjHTSWgkq1LBybmgMAEn9tJ7rHbGQH0I61zPdQ (accessed on 17 June 2020).

48. Zięba, S. Będą Nowe Ogródki za Działki Zlikwidowane pod Nową Bulońską. 2019. Available online: https://www.trojmiasto.pl/wiadomosci/Beda-nowe-ogrodki-za-dzialki-zlikwidowane-pod-NowaBulonska-n138958.html (accessed on 17 June 2020).

49. Grzenkowska, K. Piecki-Migowo. Altanki Ustępują Miejsca Nowej Bulońskiej. Available online: https://www.gdansk.pl/wiadomosci/piecki-migowo-altanki-dzialkowe-ustepuja-miejsca-nowejbulonskiej, a,76521 (accessed on 4 June 2020).

50. Naskręt, M. Ogródki Działkowe Ustapią Miejsca Nowej Bulońskiej. Jest plan Rozbiórek. 2017. Available online: https://www.trojmiasto.pl/wiadomosci/Ogrodki-dzialkowe-ustapia-miejsca-Nowej-Bulonskiej-Jestplan-rozbiorek-n110770.html (accessed on 4 June 2020).

51. Pietrzak, M. Gdańsk. Trwa Wyburzanie Ogródków Działkowych pod Nową Bulońską. 2017. Available online: https://dziennikbaltycki.pl/gdansk-trwa-wyburzanie-ogrodkow-dzialkowych-pod-nowa-bulonskazdjecia/ar/12049600 (accessed on 4 June 2020).

52. Podpisano Umowę na Zaprojektowanie Zastępczych Ogródków Działkowych na Wyspie Sobieszewskiej. Dyrekcja Rozbudowy Miasta Gdańska, 2019. Available online: http://drmg.gdansk.pl/index.php/ component/rseventspro/wydarzenie/179-podpisano-umowe-na-zaprojektowanie-zastepczych-ogrodkowdzialkowych-na-wyspie-sobieszewskiej (accessed on 17 May 2020).

53. Plany Zagospodarowania Przestrzennego. Gdańsk.pl. 2020. Available online: https://www.gdansk.pl/ zagospodarowanie-przestrzenne (accessed on 28 April 2020). 
54. BIP. Urząd Miasta Sopotu, Miejscowe Plany Zagospodarowania Przestrzennego. 2020. Available online: https://bip.sopot.pl/m,74, plany-zagospodarowania-przestrzennego-obowiazujace.html (accessed on 28 April 2020).

55. Polski Związek Działkowców, Regulamin Rodzinnego Ogrodu Działkowego. Available online: http: //www.xn--rodoazagdask-ddc.pl/regulamin_ROD.pdf (accessed on 18 May 2020).

56. Polski Związek Działkowców, Statut Polskiego Związku Działkowców. Available online: http://pzd.pl/ uploads/renata/Statut\%202017\%20zarejestrowany\%20z\%20has\%C5\%82ami.pdf (accessed on 18 May 2020).

57. Szkup, R. Użytkowanie Rodzinnych Ogrodów Działkowych (ROD) Przez Społeczność Wielkomiejska. Przykład Łodzi; Wydawnictwo Uniwersytetu Łódzkiego: Łódź, Poland, 2013.

Publisher's Note: MDPI stays neutral with regard to jurisdictional claims in published maps and institutional affiliations.

(C) 2020 by the authors. Licensee MDPI, Basel, Switzerland. This article is an open access article distributed under the terms and conditions of the Creative Commons Attribution (CC BY) license (http://creativecommons.org/licenses/by/4.0/). 